\title{
Critical Thinking and Its Assessment: A Literature Review with Special Reference in Greece and Cyprus
}

\author{
Giorgos K. Fountzoulas \\ School of Physical Education and Sports Science \\ National and Kapodistrian University of Athens \\ Athens, Greece \\ Maria I. Koutsouba \\ School of Physical Education and Sports Science \\ National and Kapodistrian University of Athens \\ Athens, Greece \\ Evgenia Nikolaki \\ School of Physical Education and Sports Science \\ National and Kapodistrian University of Athens \\ Naousa, Greece
}

\begin{abstract}
Critical thinking as a cognitive process refers to the critical thinking skills of a conscious person who explores a situation or a problem from different perspectives. In order to measure this cognitive process and skills many tools have been established. However, the accurate assessment of critical thinking skills depends on the instruments' properties being invariant or similar across cultural, ageing and other groups. For this reason, qualitative and quantitative assessments methods have been proposed and used. The aim of this study is to explore the concept of critical thinking and to present the critical thinking assessment tools used worldwide with special reference in Greece and Cyprus. For this purpose, literature-based research methodology was adopted that included analysis and evaluation of relevant published literature. The literature review showed that though many tools have been introduced for measuring critical thinking skills only thirteen of them have undergone the processes of validity and credibility procedures worldwide. Moreover, these thirteen tools include both qualitative and quantitative research methods, with qualitative ones to prevail. Finally, in Greece and Cyprus, the research of critical thinking and the assessment of critical thinking skills is a new established field and only few researches have been conducted using structured tools.
\end{abstract}

Keywords: Critical thinking, critical thinking assessment, critical thinking assessment tools, Greece, Cyprus

\section{Introduction}

Critical thinking is in prominent place among the aims and the ideals advocated by the theorists of education. As a concept, it is relatively recent, even though its fundamental principles were already recognizable by the theorists of education since ancient times (Siegel, 2003, 2010). In particular, critical thinking is one of the most important human met cognitive skills since it plays a crucial role in logical thinking, decision-making and problems solution (Heer, 2012; Fisher, 2001; Fisher \& Scriven, 1997; Paul, 1990).

More specifically, critical thinking is widely recognized as a key skill in knowledge according to most scientists since "...learning to use critical thinking is one of the most desired objectives in basic education..." (Abrami, etal., 2008:1102). Critical thinking is not only about the individual's ability to critically think in matters concerning science (such as History, Physics, Mathematics, etc.), it is also about looking with a critical eye at social, cultural and ethical challenges of everyday life, in a world of plurality and constantly increasing complexity (Facione, 1990). Despite its importance in society, many of its theorists disagree on its definition, the method of its assessment, the degree of its specialization or generalization, and the impact of its practical application in academic, professional and personal life.

Similarly, lack of consensus appears and in the case of critical thinking assessment tools since many of them was developed, in an attempt to measure and capture the skills of critical thinking. In particular, researchers in human cognition and education have developed numerous assessment tools in order to cover a broad range of formats, origins, psychometric characteristics, areas of application and scope of constructs to be measured (Abrami, et al., 2008). 
Thus, in the same vein of critical thinking's fluid concept, someone can find its tests, since every researcher delimits its concept in a particular way and, as a consequence, measures it in a particular way. This situation presents challenges in identifying, categorizing and evaluating students' outcomes in critical thinking's research in education.

\section{Aim of the study}

The aim of this study is to examine the critical thinking assessment tools and specifically the most used worldwide ones. In particular, it looks at the meaning of the concept of critical thinking and evaluates the critical thinking assessments tools with special reference in Greece and Cyprus.

\section{Methodology}

The methodological practice of this study is that of literature-based research methodology, including the analysis and evaluation of relevant published literature (Thomas \& Nelson, 2003). It is based on secondary bibliographical references (Paraskevopoulos, 1993) locally and globally through search at data bases using as key words those of critical thinking and to evaluate the critical thinking, critical thinking and education, critical thinking assessment tools, critical thinking assessment tools with special reference in Greece and in Cyprus.

\section{Critical thinking and critical thinking skills}

Many researchers have tried to define the concept of critical thinking and to give prominence to its importance since the beginning of the $20^{\text {th }}$ century (Dewey, 1997[1910]; Glaser, 1941). Its meaning has been defined in many ways throughout the time because of the complexity and the fluidity of the concepts that go hand with hand with it. As a result, its study turns to be a complicated process. On this basis, many definitions have been given over time (See,for instance, Ennis, 1962, 1987; Facione, 1990a; Kurfiss, 1988; Lipman, 1991; Paul\&Binker, 1990; Scriven\&Paul, 1996; Siegel, 1988). The most prominent one is the definition formulated in "Delphi Report" (1990) by the committee of forty-six experts of the American Philosophical Association (APA) including the experts of critical thinking Ennis, Faci one and Paul. In particular, in the definition it is mentioned that:

“...we understand to be purposeful, self-regulatory judgment which results in interpretation, analysis, evaluation, and inference, as well as explanation of the evidential, conceptual, methodological, criteriological, or contextual considerations upon which that judgment is based... The ideal critical thinker is habitually inquisitive well-informed, trustful of reason, open-minded, flexible, fair-minded in evaluation, honest in facing personal biases, prudent in making judgments, willing to reconsider, clear about issues, orderly in complex matters, diligent in seeking relevant information, reasonable in the selection of criteria, focused in inquiry, and persistent in seeking results which are as precise as the subject and the circumstances of inquiry permit..."(Facione, 1990a:3).

Thus, critical thinking is a process of judgment. It aims at leading someone to decide what to believe or not, and what to do in a given framework, in relation to the necessary data, using all the suitable syllogisms and methods, and establishing the right criteria for this act (Facione \& Facione, 2008).

\section{A literature review of critical thinking skills assessment tools}

The way critical thinking is approached arises a number of questions regarding its conceptualization and, consequently, its way of teaching. In particular, on one hand, critical thinking is considered to be solely a general skill, while, on the other, it is perceived as a combination of general and special skills with multiple levels and applications. Moreover, if critical thinking is viewed as a general skill, then it is applicable to different areas of query such as engineering, arts, physics and others (Ennis, 1989) and, thus, it can be taught through certain discussing tangible problems in each area of query (Halliday, 2000; McPeck, 1981; Smith, 2002). However, if it is considered as a special skill, then it should be taught through specific courses that focus only on critical thinking (Royalty, 1991; Sa, Stanovich, \&West, 1999).

Through the review of bibliography, however, and additional question regards the way critical thinking could be measured because of the fluidity of the concept. The researchers of critical thinking in education and in human cognitive skills have used a large number of assessment tools to cover different aspects of critical thinking such a wide range of psychometric characteristics, fields of application and range of origin. This situation challenges the processes of identifying, categorizing and assessing the students' results during the empirical study of critical thinking in educational contexts. Moreover, even when the researchers explicitly state that they assess critical thinking, it is still challenging to ensure that the outcomes represent the structure of critical thinking as it has been defined by its experts.

More specifically, the written recording of an individual's views consists the first way of measurement and assessment of the critical thinking skills. In particular, Paul (1990) claims that writing essay proves the pure knowledge of the meaning of words and sentences. 
Moreover, the application of the appropriate vocabulary, the ability of critical reading skill and the ability of critical writing shows one person's ability "...to organize, involve and develop its abilities in order to contribute to the development of its critical and creative thinking..." (Paul, 1990:56). Through the years, many more ways of assessment and measurement of critical thinking skills have been developed. These ways have been emerged through the suitable configuration of the tests and include, for instance, multiple choice questions, true or false questions, solving problems, oral presentations, written individual work or team-work, and other ways of active participation of the participants (Wolcott, etal., 2002).

Nowadays, the best-known way of assessment and estimation of the level of development of critical thinking, is the use of structured questionnaires (Pomonis, 2009). In particular, a significant number of standardized questionnaires has been developed in recent years from academic and research institutions for internal, academic or even commercial use (Bers, 2005; Dary, 2000; Norris\& Ennis,1990; Wolcott, 2000). These specific assessment tools differ from one another since they depend on the concept of critical thinking, which is abstract by nature. These structured questionnaires exceed the number of fifty. However, only thirteen of them have been submitted in validity and credibility procedures. Based on this criterion, these thirteen questionnaires are presented below in chronological order: a) Watson-Glaser Critical Thinking Appraisal, b) the Ennis-Weir Critical Thinking Essay Test, c) the Cornell Critical Thinking Test, d) California Critical Thinking Skills Test (CCTST), e) California Critical Thinking Dispositions Inventory (CCTDI), f) California Measure of Mental Motivation (CM3), g) Collegiate Assessment of Academic Proficiency (CAAP), h)

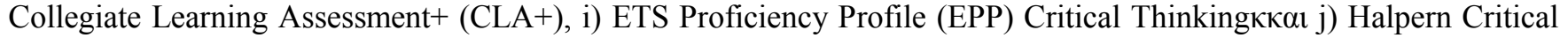
Thinking Assessment (HCTA). From the aforementioned valid and credible tests, the review of bibliography showed that other have been used by university institutions, other by international organizations and other by multinational companies. In addition, it is ascertained that not all of them have been widely used in scientific frameworks. Taking the above as criteria, the tests that have been used more frequently worldwide in different scientific branches are presented below.

\subsection{Watson-Glaser Critical Thinking Appraisal (WGCTA)}

Watson-Glaser Critical Thinking Appraisal (Watson \& Glaser, 1980; McMillan 1987) is the oldest and most popular tool used in critical thinking assessment (Spicer \& Hanks, 1995). Later, this tool was developed and, as a result, other versions of the tool appeared in bibliography, that is the Watson-Glaser II Critical Appraisal and the Watson-Glaser Critical Thinking Appraisal Form Short (WGCTA-FS) (Watson \& Glasser, 1994a, 1994b). This tool has been applied for the measurement of critical thinking in a number of occasions: of secondary school students (Dixon, etal, 2005),for the relation between critical thinking and the previous and existing political situation of the country (Kourilsky, 1972), for the interrelation of their personal prestige with critical thinking (Sandhu \& Sharma, 2015), for the relation between creativity and critical thinking in secondary school students in Taiwan (Yang \& Lin, 2004), for its cultivation in students who participated in the "service-learning" program (Goldberg\&Coufal, 2009), as a tool for the ascertainment of the importance of critical thinking in the prediction process of the secondary education students' progress check (Jenkins, 1998).It has also been used in Iranian students who attended English language courses (Hashemi \& Zabihi, 2012), for the students' performance in TOEFL reading exams (Fahim, Bagherkazemi, \& Alemi, 2010) and as the critical capability of English language teachers in relation to their professional success (Birjiandi \& Bagherkazemi, 2010).

In addition, it has been used for the measurement of critical thinking of students of the Middle East (Alshraideh, 2015), of university students in America (Obias, 2015), of pedagogy students (Gadzella, etal, 2005), of nursing students (Berger, 1984; Brooks \& Shepherd, 1990; Carole, Brown, \& Alverson, 1997; Gross, Takazawa, \&Rose, 1987; Hartley, 1994; Magnussen, Ishida, \&Itano, 2000), of pharmacy students (Miller, 2004), of occupational therapy and physiotherapy students (Vogel, etal, 2009), of students of business administration (Coleman, Mason, \& Steagall, 2012), and for the comparison between students and graduates of special education schools (Zascavage, Masten, \& Nichols, 2007), of students for the relation of critical thinking with the behavior on the role of woman in modern society (Loo \& Thorpe, 2005), for the comparison of critical thinking skills between students and graduates of special education schools (Zascavage, Masten, \&Nichols, 2007; Zascavage, 2010) and, also, for trainees in United States Air Force (Stone, 2017). It has also been used to examine the interrelation between personality and intelligence in workplace (Furnham, etal, 2007), for its development in nurses who participated in a training program (Vaughan-Wrobel, O'Sullivan, \& Smith, 1997), for the training of adults who attended specific seminars of agricultural science (Latham, Rayfield, \& Moore, 2015),for a group of employees in primary production of Ireland who participated in a critical thinking development program (Heraty\& Morley, 2000), and for the relation between reflective thinking, selfregulation and academic progress in higher education (Ghanizadeh, 2016), as well as for the role of meta cognitive skills in the development of critical thinking (Magno, 2010). 
Based on this specific assessment tool many doctoral theses have been accomplished. In particular and in chronological order, Nottariani's doctoral thesis (1991) studied the critical thinking between students of two-year nursing college and those of nursing school. Then, Nathan (1997) examined the impact between two classes of nursing students in one academic year, where one of the two attended a course aiming at cultivating critical thinking. Aebersold (2008)looked at nurses' critical thinking through their behavior, which was effective for the patients in crucial moments. The same year, Ferrara (2008) examined the relation between working experience in clinical ability and leadership of nursing students and, lastly, Adams (2008) examined the nursing school students' ability in critical thinking through intervention program.

From the aforementioned it is ascertained that Watson-Glaser Critical Thinking Appraisal (WGCTA) has been used in various places all over the world, as well as, in different population groups mainly for teenagers, university students and employees. Nursing school is a common point of many researches upon which most studies have been carried out. Finally, it should be mentioned that its validation has been accomplished in Lebanon (ElHassan\& Madhum, 2006).

\subsection{Cornell Critical Thinking Test (CCTT)}

Cornell Critical Thinking Test (CCTT) (Ennis, 1962, 1987, 1989; Ennis\& Millman, 1985a, 1985b) is widely spread in research concerning critical thinking in education (Brunt, 2005) and has two levels X and Z. X has been created for students 5-12 years old and $\mathrm{Z}$ is addressed to older students aged 11-12 years old and to university level.

The above-mentioned assessment tool of critical thinking has been used worldwide, a fact which is depicted in researches carried out through it. French, etal. (2014) carried out its validation among Korean and American students with a view to conduct further research. It was also used to measure whether the improvement of cognitive skills and critical thinking would help Iranian (Salmani Nodoushan, 2016) and Malaysian (Baki, Rafik-Galea, \& Nimehchisalem, 2016) candidates succeed in English language tests, as well as to measure critical thinking of graduates of TEFL (Teaching English as Foreign Language)and of programs in Jordan (Bataineh \& Zghoul, 2006).Kusumoto (2018) in Japan useda different approach. He created an interactive learning program, and based on Bloom's revised classification, he used this particular tool to measure the development of meta cognitive skills and specifically of critical thinking through the courses of English language (Kusumoto, 2018).It has been also used in high school students in order to measure the results of special courses of critical thinking improvement (Ernst\& Monroe, 2004), as well as the percentage of influence among the quantity of courses conducted for the development of critical thinking and its development per se (Solon, 2003).

At university students' level, it has been used to ascertain the relation between critical thinking and the potential of its interpretation and implementation in research methodology matters (Collins\& Onwuegbuzie, 2000), for its assessment in psychology students (Allegretti \& Frederick, 1995), for the comparison between students of different departments yet of the same faculty who attended different psychology courses throughout the same semester (Allegretti\& Frederick, 1995) and those who used the technique of content analysis during the learning process (Solon, 2007).

\subsection{California Critical Thinking Skills Test (CCTST), California Critical Thinking Dispositions Inventory (CCTDI) \& California Measure of Mental Motivation (CM3)}

CCTST is based on the dominant meaning of critical thinking which arose from the two-year lasting program "Delphi research" of APA (American Philosophical Association) and as formulated in «Critical thinking a statement of expert consensus for purposes of educational assessment and instruction» (Facione, 1990a). The tool measures the basic core skills of critical thinking (Facione, 1990a). It was created to measure critical thinking in people of the age group of university students and resembles WGCTA.

This particular tool is widely known since the validation and credibility of its Persian version have been confirmed in nurse university students in Tehran (Khalili \& Hossein Zadeh, 2003). The interrelation between CCTST Form Aand CCTST Form B has also come to fruition among high school students (Jacobs, 1999). It has been used in university students' level for the ascertainment of critical thinking related to differences between men and women and for the performance in English language learning tests (Tous, Tahriri, \& Haghighi, 2015), for the assessment of critical thinking among business administration university students (Bycio \& Allen, 2009), in nursing students about the relation of the reflective writing and the development of critical thinking (Kennison, 2006), in nursing students about the relation of active learning with critical thinking (Kaddoura, 2011) as well as for the comparison among students of different schools of nursing in relation to critical thinking (Soukup, 1999) and even in nursing school graduates (McMullen \& McMullen, 2009). Lastly, it has been used to ascertain the differences of critical thinking among students of public schools, Christian schools and homeschooled students (Sutton \& deOliveira, 1995). 
On the other hand, CCTDI was created after CCTST by Facione's team and aimed at measuring the full extend of an individual's critical thinking. Despite its level of detail, this measuring system of critical thinking has not been used except for the case of measuring critical thinking in pedagogy university students in Turkey. Nonetheless it is jointly used with CCTST and in particular as its supplement. These tests have been used along to ascertain the differences in the ability of critical thinking among active secondary school chemistry teachers and chemistry teachers who have not worked yet (Zhou, etal., 2012), in nursing university professors (Raymond \& Profetto-McGrath, 2005) as well as in nurses considering their critical thinking with regard to their calmness at work (May, Edell, Butell, Doughty, \&Langford, 1999).

In university students' level, the critical thinking of pharmacy students has been studied and assessed (Cisneros, 2009; Miller, 2003; Phillips, Chesnut, \& Rospond, 2004) and also the relation of creative teaching methods and of critical thinking in nursing students (Lee, etal., 2016). Also, it has been used in order to assess critical thinking of two-year nursing programs graduates (McCarthy, etal., 1999).

Lastly, CM3 is the most recent test of Facione's team. This particular test was developed in order to measure whether an individual is cognitively and intellectually mobilized with regard to intellectual activities entailing logical justification in students of secondary education (Urdan \& Giancarlo, 2001). CM3 is the main measuring means of critical thinking and it is not used in combination with the above. It has been used in students to measure the results of environmental education in relation to the development of critical thinking (Ernst\& Monroe, 2004), the relation between interactive learning, critical thinking and students' motives (Dadach, 2013) as well as the validity of the prediction of critical thinking in average rating secondary education students (LaVenia, Pineau, \&Lang, 2010). It has been validated in students in Turkey (Ozdemir \& Demirtasli, 2015), it has been used in Qassim university students in Saudi Arabia to measure critical thinking and their spiritual motives in relation to the prognosis of their academic advancement (AlShraim, 2016), for the assessment of the relation between motives and goals achievement and critical thinking (Semerci, 2010), of the relation between academic performance, critical thinking and cognitive motivation during studying in design engineering school (Mentzer \& Becker, 2009, 2010; Mentzer, 2008) and the expected improvement of critical thinking and of the problem solving ability through cognitive apprenticeship (Walker, 2003).

\subsection{Collegiate Assessment of Academic Proficiency (CAAP)}

Collegiate Assessment of Academic Proficiency (CAAP) is a known test which was created in order to measure critical thinking in post-secondary students (CAAP, Technical Handbook, 2000). This particular test includes multiple choice questions and a written essay. This assessment has been used mostly from researchers during their academic survey and in conjunction with ACT (American College Testing Program)(ACT, 2003a, 2003b, 2003c). It is a general test that measures among other abilities, critical thinking too.

In particular it has been used in university students (Klassen, 2001), to associate critical thinking abilities with their degrees in general education on a semester (Hansen, 1997), to measure learning in students' general education program (Bryant, 2000), critical thinking after the intervention program carried out at first-year university students who attended English and Mathematics courses (Toppin \& Chitsonga, 2016), the relation of critical thinking with university teaching practices and more particularly the differences between students' self-report and the direct assessment (Shim\& Walczak, 2012). Also, it has been used to measure the relation between critical thinking skills and grading in courses which claim to develop it (Sisung, 2005).

In general, this assessment tool has been used widely in the era of college students' cognitive skills. For that reason, it has been one of the most used tests in the first decades of critical thinking assessments in the U.S.A.

\section{Critical thinking assessment in Greece and Cyprus}

In Greece and Cyprus, the interest towards the critical thinking development and assessment is rather recent. In particular, it was only at the beginning of the $21^{\text {st }}$ century that the initial efforts of systematic research in this field took place by using either quantitative or qualitative ways or a combination of them. Because of that, very few researches have been carried out, which are presented below in chronological order.

More specifically, Syriopoulos and Pomonis (2007) were the first researchers that measured and assessed critical thinking skills in Greece. Their research regarded the teaching styles and the critical thinking skills through the study of sixty-eight post-graduate degree holders in vocational education. Their research had two phases during which all the examinees participated. The first phase was conducted in the spring of 2005, when the Kolb's Learning Style Inventory (LSIv.3) questionnaire was used. The second one was in the winter of 2005-2006 during which the California Critical Thinking Skills Test (CCTST) questionnaire was applied. The results showed that the prevailing teaching styles were the 'assimilating' and the 'converging' ones. 
Students became more "balanced" readers between the two phases, since this balance is related to both the "tangibleabstract" and the "active-reflective" dimension of teaching process. The emphasis was on the "active-reflective" dimension, since it is mostly related to critical thinking skills, a fact proven by the tests used (Siriopoulos\& Pomonis, 2009).

Furthermore, in his doctoral thesis, Pomonis (2009) studied the effect of applicable teaching strategies for teaching finance on forming university students' learning strategies and on developing critical thinking skills, using the economic technique "quantile regression" (QR). Forming leaning strategies were reflected with the use of Kolb's Learning Style Inventory (LSI) and Honey and Mumford's Learning Styles Questionnaire (LSQ). For the assessment of critical thinking skills, the reseracher used the California Critical Thinking Skills Test (CCTST). The research was carried out also in two phases: the first one entailed the assessment of learning processes though LSQ and LSI, while the second the assessment of learning processes through LSI and the critical thinking skills through CCTST. It was showed that each formed learning environment had a different effect on each sharing part of the dependent variable, the development of balanced preference to the ways of learning in relation to the selective preference was more beneficial for the development of critical thinking skills and that the interaction developed among university students had a positive assessment in the development of critical thinking skills.

Moreover, in his senior thesis, Poulios (2010) studied critical and creative thinking through the use of creative essay during the writing course of a high school senior class. For that purpose, the researcher conducted an interventional stage through teaching the writing course, which was described as "an intervention of experimental nature". Preexperimental control was not conducted. Instead of that, the researcher processed and assessed the participants' texts during the previous school year. Poulios carried out an interventional program that consisted of three weekly meetings of sixty minutes promoting the development of critical thinking in a creative way. In particular, the process consisted of seven phases: 1) the preparation of the teaching context, 2) the conceptual decoding of the text, 3) the conceptual deepening of the text,4) them orphological analysis of the text, 5) the personal reconstruction of the text, 6) the exercises and 7) the assessment. The assessment of data obtained from the written texts followed a model of three stages that were: a) the writing considered as a whole, as a targeted textual discourse, b) the writing examined in its parts and c) the vocabulary assessment. It was showed that the creative essay assisted in the development of creative and critical thinking. The researcher suggested the implementation of such courses that promote creative and critical thinking in elementary and secondary school.

A further research was carried out in the doctoral thesis of Vasiliadis (2014) who used the technique of arguments map applied through computer. The technique was used as a tool to ascertain whether it reinforces the acquisition and encourages the use of argumentation skills in critical thinking. For that purpose, three classes of sixth grade of elementary school were chosen to form three groups, two experimental and one control. There search took place during the course on Greek Language. The first experimental group used the Rationale software, which helps students create, organize and operate arguments' maps. The second one used worksheet that included the same argumentation activities with the students of the first experimental group but did not use the Rationale software. Lastly, the third experimental group used argumentative texts and activities like the ones presented in the textbooks of Greek Language in sixth grade, without receiving any other teaching intervention. The results showed that, in the pre-experimental test, the two thirds of the students participating in the research got an eliminatory mark which proved that they did not have critical thinking and argumentation skills. The results of the post-experimental test showed that the percentage of students who got an eliminatory mark was decreased. The researcher attributed this result to the first experimental group that manifested a better performance on average (Vasiliadis, 2014).

In her doctoral thesis, Dima (2016) studied whether an interventional program based on educational drama could ameliorate the critical thinking skills of fifth grade students. For this purpose, the researcher created a program based on educational drama which came to fruition in twelve meetings. The research process used a semi-experimental plan with pre-tests and post-tests of assessment. There were two sources of data, a quantitative and a qualitative. In particular, Cornell Class-Reasoning Test (Form X) was used, which was given to the members of the experimental group and the control group before and after the interventional program, and also the qualitative methodological practice of participatory observation. The data obtained were processed with the SPSS program with the t-student criterion for dependent samples. Then, the method of triangulation was used in order to extract valid results. From the above-mentioned process it could be argued that the educational drama in education is able to reinforce critical thinking skills of fifth grade elementary school students (Dima, 2016).

In her senior thesis, Kalogeraki (2018) studied puppetry as a means of cultivating creative thinking of school age children. Her research did not aim basically at studying critical thinking, but as a result of the development of creative thinking, critical thinking was studied as well. 
In particular, the purpose of the research was the investigation of creative thinking in fourth grade elementary school students focusing on its verbal and figural form on the basis of fluency, versatility and originality. Students of one elementary school in Argos were the sample and the interventional program lasted twelve weeks. The program had four phases where children a) were viewers of puppetry performances, b) turned into puppets and settings' makers, c) became scriptwriters and d) animators. For the assessment of data the Test Torrance of Creative thinking (Verbal, Figural), observation and portofolio were used. In order to extract results, the results of the quantitative tests were brought together through t-test for dependent samples with the qualitative data obtained from content analysis. From the above it could be argued that creative thinking of the children from the experimental group was ameliorated, after the implementation of the interventional program.

In her senior thesis, Molfesi (2018) studied the importance of musical training in the education of primary education teachers, the contribution of musical practices in the sensitization of teachers, the development of creativity and aesthetic perception, as well as the cultivation of critical thinking. The pinpointing of music as an alternative form in the framework of adults' education was a parallel objective of the research in the general concept of alternative learning. The methodological process which follows is that of triangulation through questionnaires, interviews and observation of teachers applying the suggested teaching method which they were taught in training seminars. The results of the research show that through the musical training of teachers, aesthetic perception is increased and stimuli which aim at the implementation of a multidimensional teaching methodology in action are created, imagination is developed, student-centered teaching is promoted and critical thinking is cultivated.

In short, it is showed, in relation to critical thinking, seven scientific researches have been taken place in Greece. Two of them have used exclusively qualitative ways of measuring and assessing critical thinking (Molfesi, 2018; Poulios, 2010) by using writing essays (Poulios, 2010) and a combination of questionnaire-interview-observation (Molfesi, 2018).Three researches have used exclusively experimental methods (Vasiliadis, 2014; Pomonis, 2009; Siriopoulos \& Pomonis, 2007) and, more specifically, two of them used Kolb's LSI and California Critical Thinking SkillsTest (CCTST), while the third one the arguments' maps (Vasiliadis, 2014). Finally, two researches used a combination of qualitative and quantitative methods of critical thinking assessment (Dima, 2016; Kalogeraki, 2018) by adopting Cornell Class-Reasoning Test (FormX) and participatory observation, as well as, the combination of Test Torrance of Creative thinking (Verbal, Figural), observation and portfolio (Kalogeraki, 2018).

\section{Discussion - Conclusion}

From the aforementioned literature review it is showed that critical thinking constitutes afluid concept that has many dimensions and may refers to various skills. Consequently, many tools have been introduced in bibliography for its assessment and measurement including both qualitative and quantitative research methods, though qualitative ones prevail. These tools that are presented in this paper, meeting the requirement of being under validation and credibility, appeal worldwide and in a number of subjects, ages, gender etc. However, it should be noted that, in many cases, given the fact that their use was considered unsatisfactory in certain population groups, or for some psychometric characteristics, these tools have received criticism for their methodology and content from many researchers. Because of this, either readjustments of the tools have taken place, or additional qualitative tools such as personal interview and observation have been used. Additionally, these readjustments or/and additions were mainly occurred in the field of nursing, where critical thinking assessment tools have been widely used. Moreover, it is showed that in Greece and Cyprus the research about critical thinking is still in early stages since very few researches have been conducted using structured tools. This can be attributed to the fact that critical thinking and, consequently its assessment, is a new established field in this country. Yet, this deficiency opens up a great, unexplored field to be covered through further study.

\section{References}

ACT, Inc. (2003a). CAAP user norms, Fall 2003. Iowa City, IA: Author.

ACT, Inc. (2003b). CAAP planning and forms package: A user's guide for outcomes assessment. Iowa City, IA: Author. ACT, Inc. (2003c). CAAP standard reporting and research services. Iowa City, IA: Author.

Abrami, P., Bernard, R., Borokhovski, E., Wade, A., Surkes, M., Tamim, R., \& Zhang, D., (2008). Instructional interventions affecting critical thinking skills and dispositions: a stage 1 meta-analysis. Review of Educational Research, 78(4), 1102-1134.

Adams, L. (2008). Critical thinking skills of baccalaureate nursing students. Unpublished Doctoral Dissertation. Ohio: Capital University. 
Aebersold, M.L. (2008). Capacity to rescue: Nurse behaviors that rescue patients. Unpublished Doctoral Dissertation. University of Michigan, School of Nursing.

Alshraideh, M. (2015). The effect of Suchmans' inquiry model on developing critical thinking skills among university students. International Journal of Advanced Engineering and Science, 4(1), 58-69.

Al Shraim, A.A. (2016).bility of Mental Motivation to Predict Academic Achievement among a Sample of Qassim University Students, Journal of Educational and Psychological Studies, 10(2), 35-49.

Baki, N.U., Rafik-Galea, S., \&Nimehchisalem, V. (2016). Malaysian rural ESL students critical thinking literacy level: a case study. International Journal of Education \& Literacy Studies, 4(4), 71-80.

BatainehR.F., \&Zghoul, L.H. (2006). Jordanian TEFL graduate students' use of critical thinking skills (as measured by the Cornell critical thinking test, level z). International Journal of Bilingual Education and Bilingualism, 9(1), 33-50.

Belinsky, S. B. (2000). The effect of a peer to peer strategy within radiation therapy and nursing clinical settings on the development of critical thinking skills. Unpublished Doctoral Dissertation. University of Massachusetts, Lowell.

Berger, A. (1985). Review of Watson-Glaser Critical Thinking Appraisal. In J. V. Mitchell (Ed.), Ninth mental measurements yearbook (pp. 1692-1693). Lincoln, NE: University of Nebraska-Lincoln, Buros Institute of Mental Measurements.

Berger, M. (1984). Clinical thinking ability and nursing students. Journal of Nursing Education, 23(7), 306-308.

Bers, T. (2005). Assessing critical thinking in community colleges, New Directions for Community Colleges, 130, 1525.

Birjandi, P., \&Bagherkazemi, M. (2010). The relationship between Iranian EFL teachers' critical thinking ability and their professional success. English Language Teaching, 3(2), 135-145.

Brooks, K., \& Shepherd, J. (1990). The relationship between clinical decision-making skills in nursing and general critical thinking abilities of senior nursing students in four types of nursing programs. Journal of Nursing Education, 29(9), 391-399.

Brunt, B. (2005). Models, measurement, and strategies in developing critical-thinking skills. The Journal of Continuing Education in Nursing, 36(6), 255-262.

Bryant, D. (2000). Prediction of CAAP scores based on ACT scores, cumulative GPAs, and both. In Proceedings of "The annual meeting if the Mid-South Educational Research Association" (pp. 1-28), TN, Memphis.

Bykio, P., \& Allen, J.S. (2009). The California critical thinking skills test and business school performance. American Journal of Business Education, 2(8), 1-8.

Carole, P., Brown, J., \&Alverson, E. (1997). A comparison of critical thinking abilities between accelerated and traditional baccalaureate nursing students. Journal of Nursing Education, 36(1), 46-48.

Cisneros, R. (2008). Assessment of critical thinking in pharmacy students. American Journal of Pharmaceutical Education, 73(4), 1-7.

Coleman, J., Mason, P., Steagall, J. (2012). Does a business curriculum develop or filter critical thinking?.American Journal of Business Education, 5(4), 409-416.

Collins, K., \& Onwuegbuzie, A. (2000). Relationship between critical thinkinh and performance in research methodology course. In Proceedings of Annual meeting of the Mid-South Educational Research Association (pp. 1-24). Kentucky: Lexigton.

Cubukcu, Z. (2006). Critical thinking dispositions of the Turkish teacher candidates. The Turkish Online Journal of Educational Technology (TOJET), 5(4), 22-36.

Daley, B., Shaw, C., Balistrieri, T., Glasenapp, K., \&Piacentine, L. (1999). Concept maps: a strategy to teach and evaluate critical thinking. Journal of Nursing Education, 38(1), 42-47.

Dewey, J. (1997[1910]). How we think. Boston: D.C. Heath \& Co.

Dima, A. (2016). There inforcemen to fcritical thinking skills through educational dramainfifth grade elementary school students: are search in the schools of Argolis. Doctoral thesis. University of the Peloponnese, School of Fine Arts, Theatre Studies Department.

Dadach, Z.E. (2013). Quantifying the effects of an active learning strategy on the motivation of students, International Journal of Engineering Education, 29(4), 904-913.

Dary, E.T. (2000).The NPEC Sourcebook on assessment, volume 1 \& 2: definitions and assessment methods for critical thinking, problem solving, and writing. USA: National Postsecondary Education Cooperatice.

Dixon, F., Jerrell, C., Cross, T., \& Williams, D. (2005). Effects of technology on critical thinking and essay writing among gifted adolescents. The Journal of Secondary Gifted Education, 16(4), 180-190.

El Hassan, K., \&Madhum, G. (2006). Validating the Watson Glaser critical thinking appraisal. Higher Education, 54, 361-383. 
Ennis, R.H. (1962). A concept of critical thinking: A proposed basis for research in the teaching and evaluation of critical thinking ability. Harvard Educational Review, 32(1), 81-111.

Ennis, R.H. (1987). A taxonomy of critical thinking dispositions and abilities. In J. Baron \& R. Sternberg (eds.), Teaching thinking skills: Theory and practice (pp. 9-26). New York: W. H. Freeman.

Ennis, R.H. (1989). Critical thinking and subject specificity: Clarification and needed research. Educational Researcher, 18(3), 4-10.

Ennis, R. H., \&Millman, J. (1985a). Cornell Critical Thinking Test, Level X. Pacific Grove, CA: Midwest.

Ennis, R. H., \&Millman, J. (1985b). Cornell Critical Thinking Test, Level Z. Pacific Grove, CA: Midwest.

Ernst, J., \& Monroe, M. (2004). The effects of environment-based education on students' critical thinking skills and disposition toward critical thinking. Environmental Education Research, 10(4), 507-522.

Facione, P.A., \&Facione, N.C. (1992). The California critical thinking disposition inventory test manual. Millbrae, CA: California Academic.

Facione, N.C, \&Facione, P.A. (2008). Critical thinking and clinical judgment. In N.C. Facione\& P.A. Facione (eds.), Critical thinking and clinical reasoning in the health sciences: an international multidisciplinary teaching anthology (pp. 1-15). U.S.A.: The California Academic Press.

Facione, P.A. (1990). California critical thinking skills test manual. Millbrae, CA: California Academic Press.

Facione, P.A. (1990a). Critical thinking: a statement of expert consensus for purposes of educational assessment and instruction. Research findings and recommendations. Newark, DE: American Philosophical Association.

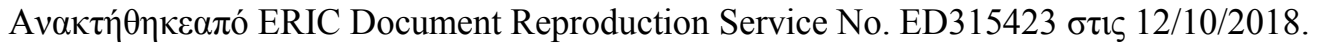

Fahim, M., Bagherkazemi, M., \& Alemi, M. (2010). The relationship between test takers' critical thinking ability and their performance on the reading section of TOEFL. Journal of Language Teaching and Research, 1(6), 830837.

Ferrara, L.R. (2008). Relationship of work experience to clinical and leadership competence of advanced practice nursing students. Unpublished Doctoral Dissertation. University of Phoenix, School of Advanced Studies.

Fisher, A. (2001). Critical Thinking: An Introduction. Cambridge University Press, UK.

Fisher, A., \& Scriven, M. (1997). Critical thinking: Its definition and assessment.UK: Cutting EdgePress.

French, B., Hand, B., Nam, J., Yen, H.J., \& Vazquez, J.A. (2014). Detection of differential item functioning in the cornellcritiscal thinking test across Korean and North American students. Psychological Test and Assessment Modeling, 56(3), 275-286.

Furnham, A., Dissou, G., Sloan, P., \& Chamorro-Premuzic, T. (2007). Personality and intelligence in business people: a study of two personality and two intelligence measures. Journal of Business Psychology, 22, 99-109.

Gadzella, B., Stacks, J., Stephens, R., \&Masten, W. (2005). Watson-Glaser critical thinking appraisal, Form-S for education majors. Journal of Instructional Psychology, 32(1), 9-12.

Ghanizadeh, A. (2016). The interplay between reflective thinking, critical thinking, self-monitoring, and academic achievement in higher education. The International Journal of Higher Education Research, 74, 101-114.

Goldberg, L., \&Coufal, K. (2009). Reflections on service-learning, critical thinking, and cultural competence. Journal of College Teaching \& Learning, 6(6), 39-49.

Gordon, J. (2000). Congruency in defining critical thinking by nurse educators and non-nurse scholars. Journal of Nursing Education, 39(8), 340-351.

Gross, Y., Takazawa, E., \& Rose, C. (1987). Critical thinking and nursing education. Journal of Nursing Education, 26(8), 317-323.

Halliday, J. (2000). Critical thinking and the academic vocational divide. Curriculum Journal, 11(2), 159-175.

Hansen, J. (1997). Community college general education impact on student critical thinking ability. PhD thesis. Iowa State University, Graduate College, Department of Philosophy.

Hartley, D. (1994). Critical thinking ability of nurse educators and nursing students. Journal of Nursing Education, 33(1), 34-35.

Hashemi, M.R., \&Zabihi, R., (2012). Does critical thinking enhance EFL learners' receptive skills?.Journal of Language Teaching and Research, 3(1), 172-179.

Heer, R. (2012).A model of learning objectives, based on a taxonomy for learning, teaching, and assessing: arevision of Bloom's taxonomy of educational objectives. Iowa State University Centerfor Excellence in Learning and Teaching -Retrieved from http://www.celt.iastate.edu/teaching-resources/effectivepractice/revised-bloomstaxonomy/ at 15 September of 2018.

Heraty, N., \& Morley, J. (2000). The application of the structure of intellect programme A manufacturing facility experiment. Journal of Managerial Psychology, 15(7), 691-715.

Jacobs, S. (1999). The equivalence of forms A and B of the California critical thinking skills test. Measurement and Evaluation in Counseling and Development, 31(4), 211-222. 
Jenkins, K.E. (1998). The significant role of critical thinking in predicting auditing students' performance. Journal of Education for Business, 73(5), 274-279.

Vogel, K., Geelhoed, M., Grice, K., \& Murphy, D. (2009). Do occupational therapy and physical therapy curricula teach critical thinking skills?.Journal of Allied Health, 38(3), 152-157.

Kaddoura, M. (2011). Critical thinking skills of nursing students in lecture-based teaching and case-based learning. International Journal for the Scholarship of Teaching and Learning, 5(2), 1-18.

Kennison, M.M. (2006). The evaluation of students' reflective writing for evidence of critical thinking. Nursing Education Perspectives, 27(5), 269-273.

Khalili, H., \& Hossein Zadeh, M. (2003). Investigation of reliability, validity and normality Persian version of the California Critical Thinking Skills Test; Form B (CCTST). Journal of Medical Education, 3(1), 29-32.

Klassen, P. (2001). General education skills development. An analysis of students' general educational skills development at college of DuPage utilizing three years CAAP testing - 1999, 2001. PhD thesis. College of DuPage, Glen Ellyn, Il.

Kourilsky, M. (1972). Learning through advocacy: an experimental evaluation of an adversary instructional model. Journal of Economic Education, 3(2), 86-93.

Kurfiss, J. K. (1988). Critical thinking: Theory, research, practice, and possibilities. Washington, D.C.: Association for the Study of Higher Education.

Kusumoto, Y. (2018). Enhancing critical thinking through active learning. Language Learning in Higher Education, $8(1), 45-63$.

Latham, L., Rayfield, J., \& Moore, L. (2015). Influence of FFA activities on critical thinking skills in Texas three-star FFA chapters. Journal of Agricultural Education, 55(5), 126-139.

Lee, J., Lee, Y., Gong, S., Bae, J., \& Choi, M. (2016). A meta-analysis of the effects of non-traditional teaching methods on the critical thinking abilities of nursing students. BMC Medical Education, 16, 240-249.

Lipman, M. (1991). Thinking in education. Cambridge, UK: Cambridge University Press.

Loo, R., \& Thorpe, K. (2005). Relationships between critical thinking and attitudes toward women's roles in society. The Journal of Psychology, 139(1), 47-55.

Magno, Carlo (2010). The role of metacognitive skills in developing critical thinking. Metacognition Learning, 5, 137156.

Magnussen, L., Ishida, D., \&Itano, J. (2000). The impact of the use of inquiry-based learning as a teaching methodology on the development of critical thinking. Journal of Nursing Education, 39(8), 360-364.

Malcolm, K. K. (1992). Review of Cornell Critical Thinking Tests. In J. J. Kramer \& J. C. Conoley (eds.), Eleventh mental measurements yearbook (pp. 243-244). Lincoln, NE: University of Nebraska-Lincoln, Buros Institute of Mental Measurements.

Maneval, R., Filburn, M., Deringer, S., \& Lum, G. (2011). Concept Mapping: does it improve critical thinking ability in practical nursing students?.Nursing Education Research, 32(4), 229-233.

May, B., Edell, V., Butell, S., Doughty, J., \& Langford, C. (1999). Critical thinking and clinical competence: a study of their relationship in BSN seniors. Journal of Nursing Education, 38(3), 100-110.

McCarthy, P., Schuster, P., Zehr, P., \& McDougal, D. (1999). Evaluation of critical thinking in a baccalaureate nursing program. Journal of Nursing Education, 38(3), 142-144.

McMullen, M., \& McMullen, W. (2009). Examining patterns of change in the critical thinking skills of graduate nursing students. Journal of Nursing Education, 48(6), 310-318.

McPeck, J. (1981). Critical thinking and education. Oxford, UK: Martin Robertson.

Mentzer, N. (2008). Academic performance as a predictor of student growth in achievement and mental motivation during an engineering design challenge in engineering and technology education. All Graduate Theses and Dissertations. 31. https://digitalcommons.usu.edu/etd/31

Mentzer, N., \& Becker, K. (2009).Motivation while designing in engineering and technology education impacted by academic preparation, Journal of STEM Teacher Education, 46(3), 9-112.

Mentzer, N., \& Becker, K. (2010). Academic preparedness as a predictor of achievement in an engineering design challenge, Journal of Technology Education, 22(1), 22-42.

Michael, W. B. (1995). Review of California Critical Thinking Skills Test. In J. C. Conoley\& J. C. Impara (Eds.), Twelfth mental measurements yearbook (pp. 145-146). Lincoln, NE: University of Nebraska-Lincoln, Buros Institute of Mental Measurements.

Miller, D. (2003). Longitudinal assessment of critical thinking in pharmacy students. American Journal of Pharmaceutical Education, 67(4), 890-897.

Miller, D. (2004). An assessment of critical thinking: can pharmacy students evaluate clinical studies like experts?.American Journal of Pharmaceutical Education, 68(1), 1-5. 
Nathan, Y.H. (1997). Critical thinking: impact on two classes of nursing students in an academic year. Unpublished Doctoral Dissertation. Columbia University, Teachers College.

Norris, S. P., \& Ennis, R. H. (1990). Evaluating critical thinking. Cheltenham, Vic.: Hawker Brownlow Education.

Notarianni, M. A. (1991). An investigation of the critical thinking ability of associate and baccalaureate degree nursing students. Unpublished Doctoral Dissertation. Widener University, School of Nursing.

Obias, P.H. (2015). Critical thinking of college students: inputs to teacher education curriculum. The Normal Lights, 9(2), 24-46.

Ozdemir, H.F., \&Deirtasli, N.C. (2015). Adaptation of California measure of mental motivation, Journal of Education and Training Studies, 3(6), 238-247.

Owen, S. V. (1998). Review of the Collegiate Assessment of Academic Proficiency. In J. C. Impara\& B. S. Plake (Eds.), Thirteenth mental measurements yearbook (pp. 283-285). Lincoln, NE: University of Nebraska Press.

Paul, R.W., \&Binker, A.J.A. (1990). Strategies: Thirty-five dimensions of critical thinking. In A.J.A. Binker (ed.), Critical thinking: What every person needs to survive in a rapidly changing world (pp. 305-349). Rohnert Park, CA: Sonoma State University, Center for Critical Thinking and Moral Critique.

Paul, R.W. (1990). Critical thinking: What every person needs to survive in a rapidly changing world. Santa Rosa, CA: Foundation for Critical Thinking.

Pomonis, G. (2009). Teaching strategies, learning types and critical thinking skills in teaching Finance: approach with quantileregression. Doctoral thesis. University of Patras, Department of Business Administration.

Poulios, K. (2010). Creative essay. The contribution of critical and creative thinking in production of written texts of original form. Thecaseofcreative essay of high school senior class. Seniorthesis. UniversityofThessaly, School of Humanity Studies.

Raymond, C., \&Profetto-McGrath, J. (2005). Nurse educators' critical thinking: reflection and measurement. Nurse Education in Practice, 5, 209-217.

Royalty, J. (1991). The generalizability of critical thinking: Paranormal beliefs versus statistical reasoning. Journal of Genetic Psychology, 156(4), 477-488.

Sá, W.C., Stanovich, K.E., \& West, R.F. (1999). The domain specificity and generality of belief bias: Searching for generalizable critical thinking skill. Journal of Educational Psychology, 91(3), 497-510.

Sandhu, B.S., \& Sharma, S. (2015). Role of critical thinking in ego identity statuses among adolescents. Indian Journal of Health and Wellbeing, 6(11), 1076-1079.

SalmaniNodoushan, M.A. (2016). Working on the 'write' path: improving EFL students' argumentative writing performance through L1-mediated structural cognitive modification. International Journal of Language Studies, 10(4), 131-152.

Scriven, M., \& Paul, R. (1996). Defining critical thinking: A draft statement for the National Council for Excellence in critical thinking. Retrieved 16/10/2018, from http://www.criticalthinking.org/University/univlibrary/library.nclk.

Semerci, C. (2010). The relationships between achievement focused motivation and critical thinking, African Journal of Business Management, 5(15), 6180-6185.

Shim, W.J., \& Walczak, K. (2012). The impact of faculty teaching practices on the development of students' critical thinking skills, International Journal of Teaching and Learning in Higher Education, 24(1), 16-30.

Siegel, H. (1988). Educating reason: Rationality, critical thinking, and education. New York: Routledge.

Smith, G. (2002). Are there domain-specific thinking skills? Journal of Philosophy of Education, 36(2), $207-227$.

Siegel, H. (2003). Cultivating reason. In R. Curren (ed.) A Companion to the Philosophy of Education (pp. 305-317). Oxford: Blackwell.

Siegel, H. (2010). Critical Thinking, International Encyclopedia of Education, 6, 141-145.

Siriopoulos, C., \&Pomonis, G. (2007). Learning style changes and their relationship to critical thinking skills, Journal of College Teaching \& Learning, 4(1), 45-60.

Sisung, J. (2005). Relationship between standardized critical thinking test scores and earned grades in courses purported to teach critical thinking at Kellogg community college. $\mathrm{PhD}$ thesis. Lincoln University of Nebraska, Faculty of the Graduate College.

Solon, T. (2003). Teaching critical thinking: the more, the better!.The Community College Enterprise, 9(2), 25-38.

Solon, T. (2007). Generic critical thinking infusion and course content learning in introductory psychology. Journal of Instructional Psychology, 34(2), 95-109.

Soukup, F. (1999). Assessment of critical thinking skills in associate degree nursing students. Unpublished $\mathrm{PhD}$ thesis. University of Winsconsin, The Graduate College.

Stone, C.A. (2017). Critical thinking skills in USAF developmental education. Air \& Space Power Journal, 31(3), 5267. 
Sutton, J., \& de Oliveira, P. (1995). Differences in critical thinking skills among students educated in public schools, Cristian schools, and home schools. In Proceedings of Annual Meeting of the American Educational Research Association (pp. 1-22). San Francisco: American Educational Research Association.

Thomas, J.R., \& Nelson, J.K. (2003). Research methods in physical activity.(trans. K. Karteroliotis). Athens: MedicalPublicationsP.C.Paschalidis.

Toppin, I.N., \&Chitsonga, S. (2016). Critical thinking skills and academic maturity: emerging results from a five-year quality enhancement plan (QEP) study, Journal of Inquiry \& Action Education, 7(2), 81-93.

Tous, M.D., Tahriri, A., \&Haghighi, S. (2015). The effect of instructing critical thinking through debate on male and female EFLleraners' reading comprehension. Journal of the Scholarship of Teaching and Learning, 15(4). 2140.

Urdan, T., \& Giancarlo, C. (2001). A comparison of motivational and critical thinking orientations across ethnic groups. In D. McInerney\&S.VanEtten (eds.), Research on Sociocultural Influences on Motivation and Learning (pp. 37-60). Connecticut: IAP.

Vasiliadis, I. (2010). Cultivation of critical thinking in elementary school students through the development of argumentation with the use of computer. InN. Tsaggaridou, S. Simeonidou, K. Mavrou, E. Ftiaka\&L. Kyriakidis (ed.), Management of Educational Change: Research, Policy, Action, Proceedings of the $11^{\text {th }}$ Convention of Cyprus Pedagogical Association, (pp. 450-462). Cyprus: Cyprus Pedagogical Association and University of Cyprus.

Vasiliadis, I. (2014). Cultivation of argumentation and critical thinking skills in elementary school students through arguments map. Doctoral thesis. University of Cyprus, Department of Educational Sciences.

Vaughan-Wrobel, B., O’Sullivan, P., \& Smith, L. (1997). Evaluating critical thinking skills of baccalaureate nursing students. Journal of Nursing Education, 36(10), 485-488.

Walker, D.P. (2003). Enhancing problem solving disposition, motivation and skills through cognitive apprenticeship. $\mathrm{PhD}$ thesis. North Carolina State University, Faculty of Technology Education.

Watson, G., \& Glaser, E. M. (1980). Watson-Glaser Critical Thinking Appraisal. San Antonio, TX: PsychCorp.

Watson, G. \& Glasser, E. (1994a). Watson-Glaser Critical Thinking Appraisal Form Short. San Antonio, TX: Psychological Corporation.

Watson, G., \& Glaser, E. M. (1994b). Watson-Glaser Critical Thinking Appraisal, Form Short manual. San Antonio, TX: The Psychological Corporation.

Werner, P.H. (1991). The Ennis-Weir critical thinking essay test: an instrument for testing and teaching, Journal of Reading, 34(6), 494-495.

Wolcott, S.K., Baril, C.P., Cunningham, B.M., Fordham, D.R., \&Rierre, K.S. (2002). Critical thought on critical thinking research, Journal of Accounting Education, 20, 85-103.

Wolcott, S.K. (2000). Designing assignments and classroom discussions to foster critical thinking at different levels in the curriculum, Educational Innovation in Economics and Business, 5, 231-251.

Yang, S.C., \& Lin, W.C. (2004). The relationship among creative, critical thinking and thinking styles in Taiwan high school students. Journal of Instructional Psychology, 31(1), 33-45.

Zascavage, V., Masten, W., \& Nichols, C. (2007). Comparison of critical thinking in undergraduates and graduates in special education. International Journal of Special Education, 22, 25-31.

Zhou, Q., Yan, C., Zhao, S., Liu, L., \& Xing, L. (2012). A preliminary investigation into critical thinking of inservice and pre-service middle chemistry teachers in Shaanxi province of China. Asia-Pacific Forum on Science Learning and Teaching, 13(2), 1-14.

Zygmont, D., \&ScaefermK.M. (2006). Assessing the critical thinking skills of faculty: what do the findings mean for nursing education?.Nursing Education Perspectives, 27(5), 260-268. 